\title{
Analysis of the Effect of Financial Indicators and Ratio Sharia Banking on Capital Market
}

\author{
Srie Nuning Mulatsih ${ }^{1}$, Heru Subiyantoro $^{2}$, Yolanda $^{3}$, Masruri $^{4}$ \\ \{nuningpurwanto@unis.ac.id ${ }^{1}$, heru_subiyantoro@borobudur.ac.id ${ }^{2}$, yolanda@borobudur.ac.id ${ }^{3}$, \\ masruri@gmail.com ${ }^{4}$ \} \\ Student of Doctorate of Law Study Program, Universitas Borobudur Jakarta ${ }^{1}$, Universitas \\ Borobudur Jakarta ${ }^{2,3}$, Universitas Islam Syekh-Yusuf ${ }^{4}$
}

\begin{abstract}
This research was conducted to analyze Macroeconomic Indicators (SBI Interest Rates, Exchange Rates, Inflation, Indonesian Composite Stock Price Index, GDP), and Financial Ratios (Assets, PYD, DPK, NPF, CAR, FDR, ROA and BOPO) to the Capital Market. The Sharia method used in this study is a quantitative research method using panel data analysis tools. The variables of this research are Islamic Banking and Islamic Capital Market in Indonesia during the period 2011-2019. Sources of data are taken from publications in the form of Sharia Financial Development Reports (LPKS), Islamic banking snapshoots and Financial Services Authority (OJK) Statistics. This study uses Analysis of multiple linear regressions. The results of this study suggest that, at least in part the Asset Variables, PYD, FDR, ROA and BOPO affect the Islamic Capital Market and simultaneously affect the Islamic Capital Market.
\end{abstract}

Keywords: Assets; PYD; TPF; NPF; CAR; FDR; ROA; BOPO; Islamic Capital Market

\section{Introduction}

The Indonesian economy continues to show a stable performance with a more balanced structure. This can be seen from the growth of Real Gross Domestic Product (GDP) in the last three years showing a stable trend and increasing from 5.03\% in 2016 to $5.07 \%$ at the end of 2017. Stable GDP growth is supported by stable inflation maintained in the range of $3 \pm 1 \%$ and a stable rupiah exchange rate which was in the range of Rp13,323 - Rp13,563 per USD. This shows the ongoing process of domestic economic recovery. 
Indikator Makroekonomi Indonesia 2013-2017

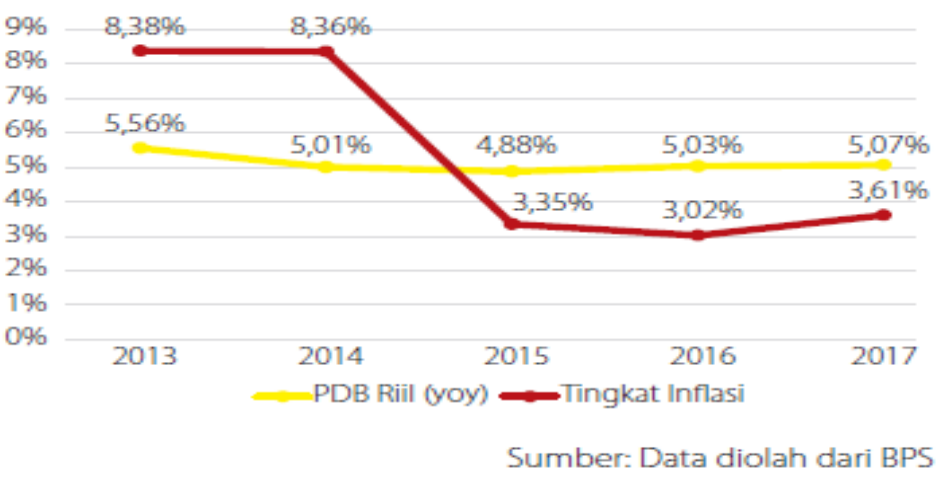

Fig. 1. Indonesia's Macroeconomic Indicators

The Islamic capital market in Indonesia has grown for two decades, starting with In 1997, sharia mutual funds were first introduced. Since then, the Indonesian Islamic capital market has continued to expand and thrive, as evidenced by the increasing number of sharia products, the issue of sharia capital market laws, and the lot of folks who are aware of and interested in the Islamic capital market. Sharia securities, such as sharia shares, sukuk, sharia mutual funds, and sharia exchange traded funds (ETF), as well as sharia services, such as sharia online trading, are among capital market instruments offered till the end of 2014 In terms of the legal framework, Indonesia already has Regulations for sharia capital markets based on a fatwa issued by the National Sharia Council of the Indonesian Ulema Council (DSN-MUI), DSN MUI Fatwa No. 40/DSN-MUI/X/2003 Concerning the Capital Market and Sharia Principles in the Capital Market Sector, and also General Guidelines for Sharia Principles Implementation in the Capital Market Sector [1].

The capital market can be used as an alternative that can be used by companies to meet the capital needs of their companies, where Existing companies sell their shares to the general public. Companies that have gone public are those that have joined the capital market. A company that has gone public is one that has registered its shares on the stock exchange. The these companies are supervised by the Capital Market and Financial Institution Supervisory Agency (Bapepam-LK), which has since become the Financial Services Authority (OJK) [2]. Figure 2 shows the growth of the Islamic stock index, which can be used to determine the performance of Islamic stock trading. The Jakarta Islamic Index (JII) and the Indonesian Sharia Stock Index were the only sharia stock indexes available until the end of 2016, according to data from the Indonesia Stock Exchange (IDX) (ISSI). 


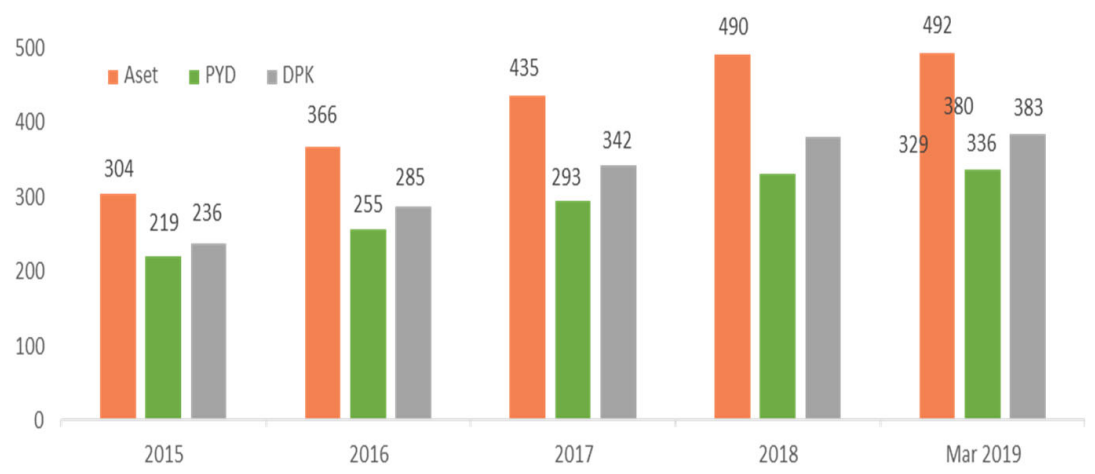

Fig. 2. Asset Development, PYD and TPF

Along with improving national economic performance, the development of the Islamic banking industry in 2017 also recorded encouraging growth in terms of assets, disbursed financing (PYD), and third party funds (DPK). The growth of Islamic banking, consisting of Sharia Commercial Banks (BUS), Sharia Business Units (UUS) and Sharia People's Financing Banks (BPRS), although slightly slowed compared to 2016, growth in assets, PYD, and DPK was still maintained at a fairly high rate (double digits), which are $18.97 \%, 15.24 \%$ and $19.83 \%$ (yoy).

Sharia banking assets in 2017 grew by $18.97 \%$ (yoy), although the growth rate was still high, but tended to experience a slowdown compared to 2016 which grew by $20.28 \%$, or grew $18.97 \%$ (yoy).[3] The factor that most influenced the slowdown in sharia banking growth was caused by the growth of BUS which fell by $5.78 \%$ or only reached $13.31 \%$ (yoy) in 2017 . The slowdown in growth in BUS had a major impact on the total growth of the sharia banking industry because BUS assets dominated the composition national Islamic banking assets amounted to $66.21 \%$. Meanwhile, UUS and BPRS experienced better growth compared to the previous year. UUS asset growth was recorded at $33.07 \%$, an increase of $9.55 \%$ compared to the previous year's growth of $23.52 \%$. Meanwhile, the growth of BPRS assets also increased from $18.32 \%$ to $18.38 \%$. [4] In nominal terms, the assets of BUS, UUS, and BPRS in 2017 were recorded at Rp.288.02 trillion, Rp.136.15 trillion, and Rp.10.84 trillion, respectively.

Slowing growth also occurred in Islamic banking Third Party Funds (DPK) and Disbursed Financing (PYD). In 2017, Sharia banking deposits grew by $19.83 \%$, a slight slowdown compared to 2016 which reached $20.84 \%$. In nominal terms, TPF for BUS, UUS, and BPRS in 2017 was recorded at Rp. 238.22 trillion, Rp. 96.49 trillion, and Rp. 6.99 trillion, respectively. Meanwhile PYD grew by $15.23 \%$, or decreased by $1.18 \%$ compared to PYD growth in 2016 which reached $16.41 \%$. In nominal terms, PYD BUS, UUS, and BPRS in 2017 were recorded at Rp. 189.79 trillion, Rp. 95.91 trillion, and Rp. 7.76 trillion, respectively [3]. 


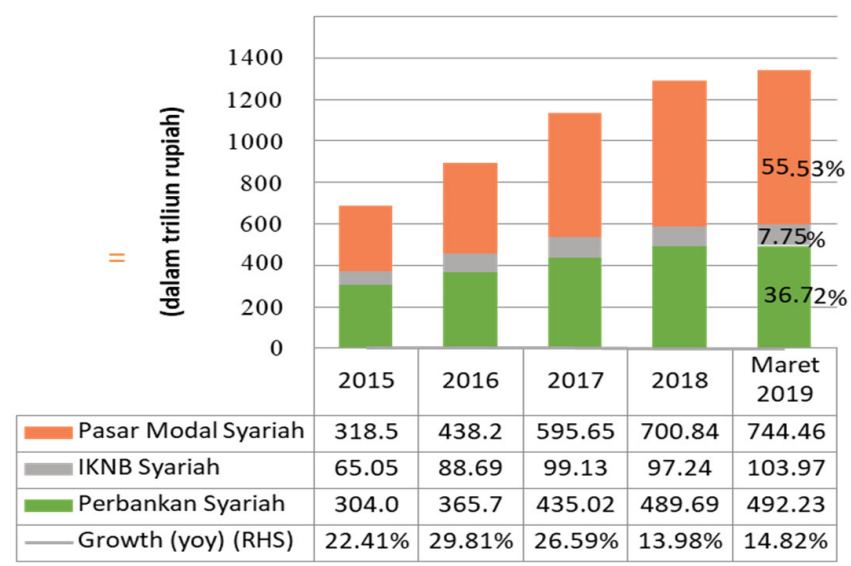

Fig. 3. Indonesian Islamic Banking Snapshoot

Based on the description above from previous research, only the independent variables were limited to interest rates, profit sharing rates, and inflation. Therefore, the authors are interested in completing the variables that have been conveyed by previous authors because in addition to the variables mentioned above, the effect on economic growth in Indonesia, with the title: "Analysis of the Effect of Islamic Banking Financial Indicators and Ratios on the Islamic Capital Market."

\section{Methodology}

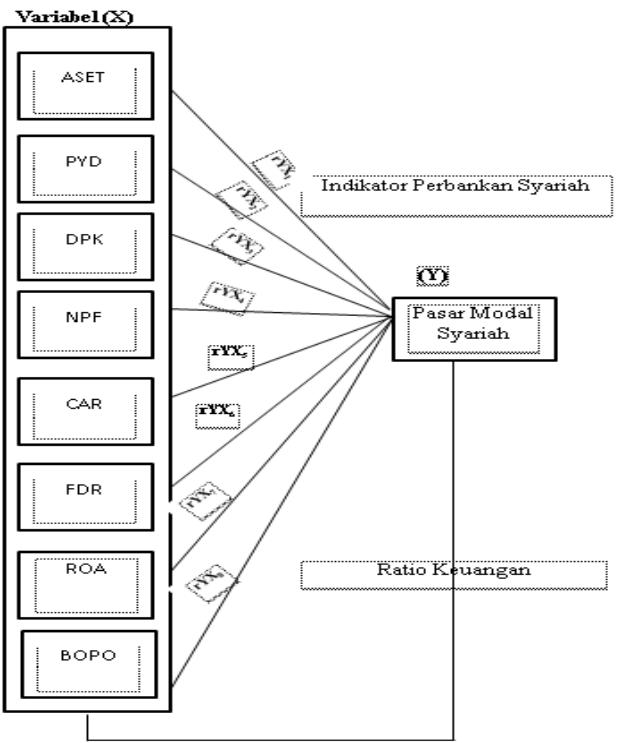

Fig. 4. Research framework 
The method utilized in this study is an associative method with a quantitative approach, which is based on the problems studied. The quantitative approach method is a research method based on the positivism philosophy that is used to investigate specific populations or samples [5]. This study takes data by purposive sampling with OJK data for the 2011-2019 period. The selected sample is registered with the OJK as many as 44 companies. Data analysis in this study used the help of computer software program SPSS version 24. This analysis aims to answer the hypothesis recommended in this study.

\subsection{Population}

A population is a generalization area made up of things or study subjects with certain attributes and characteristics that researchers have determined should be studied and conclusions drawn [5]. The population used in this study is the Jakarta Financial Authority (OJK) and the Central Statistics Agency (BPS) in 2011-2019. The sampling technique used in this study is non-random sampling, which is a non-random method in which the elements of the population do not have the same opportunity to be selected as samples and by using purposing sampling technique.

\subsection{Sample}

The sample is part of the number and characteristics possessed by the population. The sampling method aims to be used if the sample members are specifically selected based on certain considerations [5]. In this study the authors perform quantitative calculations using data related to Assets, Funding Provided, Third Party Funds, Non Performing Financing, Capital Adequacy Ratios, Financing Deposit Ratios, Return On Assets, Operational Costs and Operating Income as well as Islamic Capital Markets with samples nine years which will be used by the author to determine how much influence the financial indicators and ratios of Islamic banking on the Islamic capital market are studied and conclusions will be drawn.

\subsection{Classical Basic Assumption Test}

a) Normality test

This The One-Sample Kolmogorov-Smirnov test is used to determine if the observations are normally distributed [6].

b) Multicollinearity Test

It is a test used to detect whether symptoms of multicollinearity occur or not, namely by looking at the VIF (Variance Inflation Factor) value in the research results.

c) Heteroscedasticity Test

This test is used to identify whether or not there is a virus present heteroscedasticity, namely if the distribution of points is above and below the number (0) zero on the $\mathrm{Y}$ axis and does not form a pattern.

d) Autocorrelation Test

Testing autocorrelation in a model aims to determine whether there is a correlation between the confounding variables in a certain period and the previous variables [7].

Detect autocorrelation using Durbin Watson value with criteria if:

1. D-W numbers below -2 means that there is a positive autocorrelation.

2. A D-W number between -2 and +2 means that there is no autocorrelation.

3. D-W numbers above +2 mean that there is a negative autocorrelation. 
e) Multiple Linear Regression Analysis

According to Sugiyono, it is used by researchers, if the researcher intends to predict how the condition (up and down) of the dependent variable (criteria), if two or more independent variables as predictor factors are manipulated (increase in value) [8]. So multiple regression analysis will be carried out if the number of independent variables is at least 2. In this study, a significance level of 0.05 or 5 percent was used [5].

f) Partial Hypothesis Testing (t-Test)

To see if each independent variable has an effect on the dependent variable, use the test. The $t$ method is a standard method for determining whether or not it is calculated using the formula following:

$$
\mathbf{t}_{\text {count }}=\frac{r \sqrt{n-2}}{\sqrt{1-r^{2}}}
$$

Where:

$$
\begin{aligned}
& \mathrm{r}=\text { Correlation Coefficient } \\
& \mathrm{n}=\text { Number of Samples } \\
& \mathrm{th}=\mathrm{t} \text { count }
\end{aligned}
$$

Testing the hypothesis used the degree of confidence or the real level of $\mathrm{n}-2$ and $=0.05$, if $\mathrm{t}$ count $<\mathrm{t}$ table then Ho is accepted and $\mathrm{Ha}$ is rejected so that there is no significant relationship between $\mathrm{X} 1$ and $\mathrm{Y}, \mathrm{X} 2$ and $\mathrm{Y}, \mathrm{X} 3$ and $\mathrm{Y} ., \mathrm{X} 4$ and $\mathrm{Y}$. If $\mathrm{t}$ count $>\mathrm{t}$ table then $\mathrm{Ho}$ is rejected and $\mathrm{Ha}$ is accepted so that there is a significant relationship between $\mathrm{X} 1$ and $\mathrm{Y}$, and $\mathrm{X} 2$ and $\mathrm{Y}[9]$.

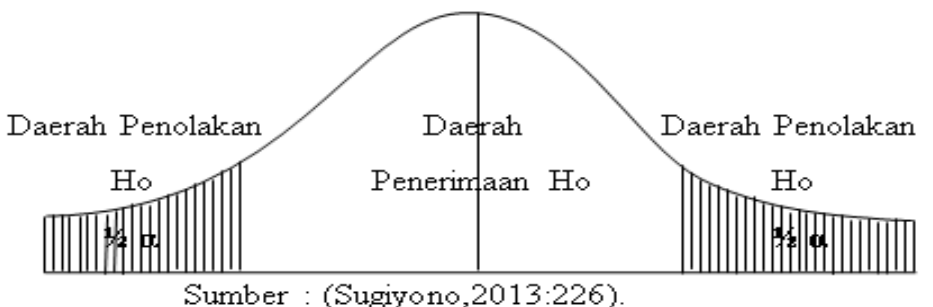

Fig. 5. Two-tail test curve

g) Simultaneous Hypothesis Testing (F Test)

The $\mathrm{F}$ test is often used for experimental design analysis. To find out the calculated $\mathrm{f}$ value, the formula is used:

$$
F \text { count }=\frac{R^{2} / K}{1-R^{2} / n-K-1}
$$

h) Coefficient of Determination

The coefficient of determination can be seen in the Adjusted R Square value which shows how much the independent variable can explain the dependent variable. The higher the Adjusted R Square value, the better the regression model used because it indicates that the ability of the independent variable to explain the dependent variable is also greater. the opposite happens. Coefficient of determination formula. 
Where:

$\mathrm{Kd} \quad=$ Coefficient of Determination

Rxy2 = Correlation between independent and dependent variables.

\section{Research Results and Discussions}

This study takes data by purposive sampling with OJK data for the 2011-2019 period. The selected sample is registered with the OJK as many as 44 companies. Data analysis in this study used the help of computer software program SPSS version 24 . This analysis aims to answer the hypothesis recommended in this study.

\subsection{Sharia Capital Market}

The capital market is defined as any activity involving public offering and trading of securities issued by public companies, as well as institutions and professions connected to securities as according Law Number 8 of 1995 concerning the Capital Market (UUPM). According this definition, Islamic capital market terminology refers to activities in the capital market that do not violate sharia principles and are regulated by the Capital Market Law The concept is the principle of Islamic capital markets in Indonesia:

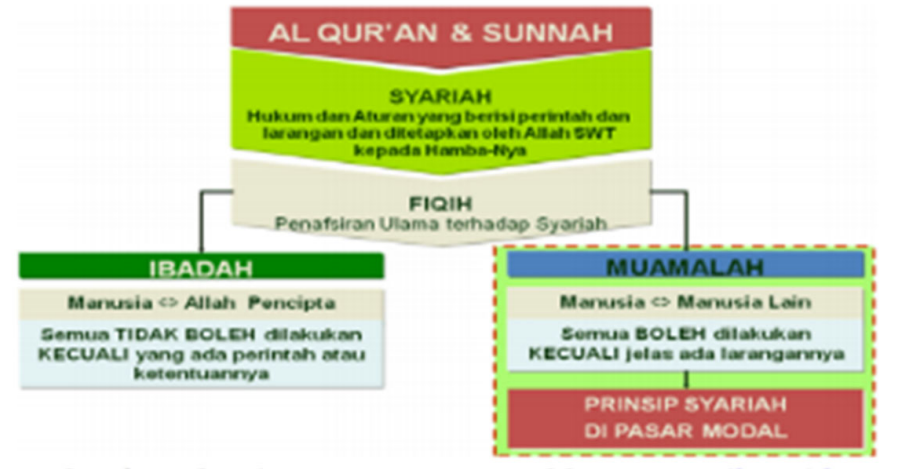

Sumber: Otoritas Jasa Keuangan, 2014 www.ojk.go.id

Fig. 6. The principle of Islamic capital markets in Indonesia (Otoritas Jasa Keuangan, 2014)

According to Law Number 10 of 1998 concerning Amendments to Law Number 7 of A bank, according the Banking Act of 1992, is a type of business that receives funds from the general public in the form of savings and distributes them to the general public in the form of credit and/or other forms in order to raise the general public's standard of living Banking is everything related to banks, concerning institutions, business activities, as well as methods and processes in carrying out their business activities. According to Muhammad in terms of interest payments or profit sharing, banks are divided into two types, namely banks that do business conventionally and banks that do business according to sharia [10]. 


\subsection{Asset}

Assets, often known as assets, are economic resources that are expected to provide future business benefits. Assets are recorded as a normal debit balance on the balance sheet.

\subsection{Funding Received (PYD)}

Sharī ah financing is money or bill financing that is based on a contract between the bank and the customer and other parties who have the obligation of the party being financed to return the money or bills after a certain period of time with rewards and profit sharing. [11].

The Word of Allah swt. in Surah Al-Nisaa (4:29)

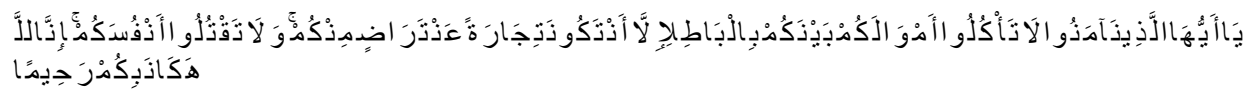

O you who believe, do not eat (take) each other's property by vanity, except by way of commerce that applies voluntarily between you. And do not kill yourselves; Verily Allah is Most Merciful to you [12].

\subsection{Third party funds (DPK)}

TPF is the largest asset and the most reliable by banks, reaching $80 \%$ to $90 \%$, TPF is one of the sources that can be used for financing. The bigger the bank is successful in collecting funds from the DPK, the greater the financing disbursed by the bank [13]. DPK is the amount of money owned by a bank where the money comes from an outside party who keeps the money or the money that is owned does not belong to the bank itself but a deposit from an outside party, and the bank here is only an institution in charge of collecting and channeling it back to the community [14].

\subsection{Non-Performing Financing (NPF)}

Non-Doing Financing (NPF) is a financial ratio how well a debt is performing that depicts the financing risk that banks face as a result of providing credit and depositing bank money in various portfolios [15].

\subsection{Capital Adequacy Ratio (CAR)}

The CAR ratio is a metric that measures a bank's capital adequacy to support risky assets. The Capital Adequacy Ratio (CAR) can be obtained using the formula [16]. CAR is a banking performance ratio that functions to measure the adequacy of capital owned by banks to support assets that are potentially exposed to risk, such as the amount of credit extended by banks [17].

\subsection{Financing Deposit Ratio (FDR)}

According to Lukman Dendawijaya in his book entitled Banking Management, states that the Financing Deposit Ratio (FDR) is the ratio between the total amount of credit granted and the funds received by the bankThe FDR, or Financing to Deposit Ratio, is a ratio use to assess 
how much money is available to borrow amount of financing provided by the amount of public funds and own capital used [18].

\subsection{Financial Ratio Analysis}

Harahap stated that financial ratios are numbers obtained from the comparison of one financial statement post with other items that have a relevant and significant relationship [19].

\subsection{Return On Assets (ROA)}

Return on Assets is a ratio used to measure management's ability to generate or gain profits for the company. The profit here is the profit after tax generated from the average total assets of the bank concerned. [20] ROA is a measure of the effectiveness of management in managing its assets [21]. The The ability of a company to generate profits by the use of its assets is measured by return on assets (ROA). Because rate of return is proportional to company size, the higher the ROA, the better the company's success success on investment is greater [6]. Return on Assets (ROA) is a ratio that shows how much net profit can be obtained from the entire wealth of the company.

Therefore, the profit after tax figure and the company's average wealth are used. Thus, this ratio relates the profits obtained from the company's operations with the amount of investment or assets used to generate operating profits [22]. According to Hery [23] return on Assets (ROA) can be calculated using several formulas as follows:

$\mathrm{ROA}=($ Net profit $) /($ Total Assets $) \times 100 \%$

The word of Allah SWT explains in the letter Ali Imran: 145

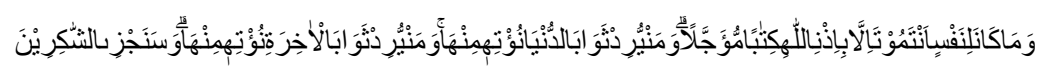

And every soul will not If Allah's permission is given, death comes at a set moment. We will certainly give the reward (of this world) to whoever desires it, and We will surely give the reward (of the hereafter) to whoever accepts it reward those who are grateful [24].

\subsection{Operating Expenses and Operating Income (BOPO)}

BOPO is a ratio used to measure a management bank's ability to control operational costs and operating income. The operating costs and operating income formula is: (Dewi Farida, et all, 2016).

\subsection{Descriptive statistics}

Descriptive statistics such as Table 1 shows the average (mean), minimum and maximum values of each variable

Table 1. Variable Descriptive Statistics Results

\begin{tabular}{cccccc}
\hline \multicolumn{5}{c}{ Descriptive Statistics } \\
\hline & N & Minimum & Maximum & Mean & Std. Deviation \\
\hline ASET & 140 & 1,02 & 874,60 & 45,0678 & 89,61629 \\
PYD & 140 &, 50 & 859,94 & 38,4175 & 98,16802 \\
\hline
\end{tabular}




\begin{tabular}{cccccc}
\hline \multicolumn{5}{c}{ Descriptive Statistics } \\
\hline & N & Minimum & Maximum & Mean & Std. Deviation \\
\hline DPK & 140 & 1,02 & 7279,00 & 101,2391 & 625,01308 \\
NPF & 140 &, 00 & 23,68 & 2,6533 & 3,17868 \\
CAR & 140 & 2,46 & 557,15 & 27,2719 & 57,52911 \\
FDR & 140 &, 17 & 162,97 & 35,6330 & 43,17859 \\
ROA & 140 & $-1077,00$ & 103,00 & $-10,2699$ & 98,34855 \\
BOPO & 140 &, 10 & 8886,00 & 143,6799 & 744,74230 \\
PMS & 140 & 1,12 & 991,65 & 169,7217 & 250,57664 \\
Valid N (listwise) & 140 & & & & \\
\hline
\end{tabular}

Source: Secondary data, processed by SPSS 24, 2020

Table 2. Normality Test Kolmogorov-Smirnov

\begin{tabular}{|c|c|c|c|}
\hline \multicolumn{4}{|c|}{ One-Sample Kolmogorov-Smirnov Test } \\
\hline & & & $\begin{array}{c}\text { Unstandardized } \\
\text { Residual }\end{array}$ \\
\hline \multicolumn{3}{|l|}{ N } & 90 \\
\hline \multirow{2}{*}{$\begin{array}{l}\text { Normal } \\
\text { Parameters }\end{array}$} & \multicolumn{2}{|l|}{ Mean } &, 0000000 \\
\hline & \multicolumn{2}{|l|}{ Std. Deviation } & 172,03730320 \\
\hline \multirow{3}{*}{$\begin{array}{l}\text { Most Extreme } \\
\text { Differences }\end{array}$} & \multicolumn{2}{|l|}{ Absolute } & .173 \\
\hline & \multicolumn{2}{|l|}{ Positive } & .173 \\
\hline & \multicolumn{2}{|l|}{ Negative } & -.138 \\
\hline \multicolumn{3}{|l|}{ Test Statistic } & .173 \\
\hline \multicolumn{3}{|c|}{ Asymp. Sig. (2-tailed) } & $.000^{\circ}$ \\
\hline \multirow{3}{*}{$\begin{array}{l}\text { Monte Carlo Sig. } \\
\text { (2-tailed) }\end{array}$} & \multicolumn{2}{|l|}{ Sig. } & $.010^{\circ}$ \\
\hline & \multirow{2}{*}{$\begin{array}{l}99 \% \text { Confidence } \\
\text { Interval }\end{array}$} & Lower Bound & .007 \\
\hline & & Upper Bound & 012 \\
\hline \multicolumn{4}{|c|}{ a. Test distribution is Normal. } \\
\hline \multicolumn{4}{|c|}{ b. Calculated from data. } \\
\hline \multicolumn{4}{|c|}{ c. Lilliefors Signific ance Correction. } \\
\hline \multicolumn{4}{|c|}{ d. Based on 10000 sampled tableswith starting seed 221623949 . } \\
\hline
\end{tabular}

Source: Secondary data, processed by SPSS 24, 2020

Table 3. Multicollinearity Test Results

\begin{tabular}{|c|c|c|c|c|c|c|c|c|}
\hline \multicolumn{9}{|c|}{ Coefficients } \\
\hline & & \multicolumn{2}{|c|}{ Unstandardized Coefficients } & \multirow{2}{*}{$\begin{array}{l}\text { Standardized } \\
\text { Coefficients } \\
\text { Beta }\end{array}$} & \multirow[b]{2}{*}{$t$} & \multirow[b]{2}{*}{ Big. } & \multicolumn{2}{|c|}{ Collinearity Statistics } \\
\hline \multicolumn{2}{|c|}{ Model } & B & Std. Error & & & & Tolerance & VIF \\
\hline \multirow[t]{9}{*}{1} & (Constant) & 158,466 & 35,083 & & 4,517 &, 000 & & \\
\hline & ASET &,- 232 & .227 &,- 083 & $-1,021$ & 309 &, 960 & 1,041 \\
\hline & PYD & .482 &, 204 & 189 & 2,359 &, 020 & 990 & 1,010 \\
\hline & DPK & .103 & .032 & .256 & 3,195 &, 002 &, 985 & 1,016 \\
\hline & NFF & 14,175 & 6,398 & 180 & 2,215 &, 028 &, 962 & 1,040 \\
\hline & CAR &,- 340 & 349 &,- 078 & -975 & 331 & ,986 & 1,014 \\
\hline & FDR &,- 896 & .473 &,- 154 & $-1,894$ &, 060 & 953 & 1,049 \\
\hline & ROA & .143 & .205 & .056 &, 697 & 487 & 978 & 1,023 \\
\hline & BOPO & -015 & .027 &,- 044 & -.550 & 583 & 989 & 1,011 \\
\hline
\end{tabular}

Source: Secondary data, processed by SPSS 24, 2020 


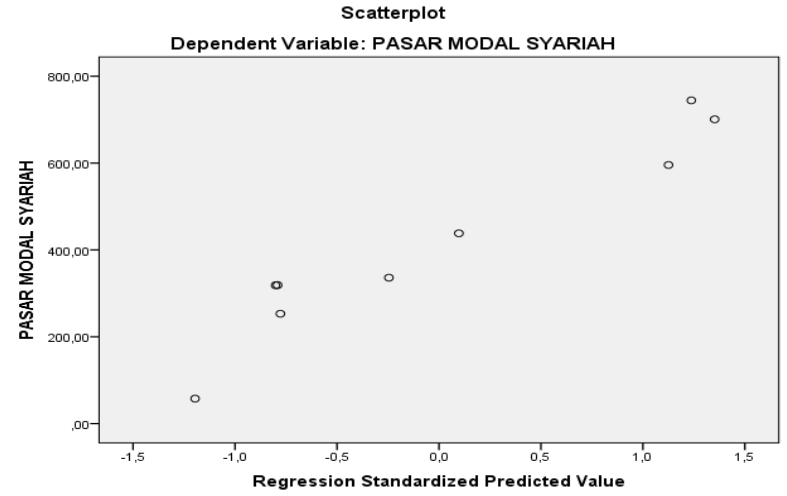

Fig. 7. Heteroscedasticity Results

From the results of data processing shows Because the independent variable does not have a VIF larger value then 10, no multicollinearity can be assumed. It can be seen from the data processing results in the figure that the distribution pattern is above and below the $\mathrm{Y}$ axis and does not form a certain pattern, it can be concluded that this model does not have heteroscedasticity disturbances.

Table 4. Autocorrelation test results

\begin{tabular}{cccccc}
\hline \multicolumn{6}{c}{ Model Summary } \\
\hline Model & R & R Square & $\begin{array}{l}\text { Adjusted } \\
\text { R Square }\end{array}$ & $\begin{array}{c}\text { Std. Error of } \\
\text { the Estimate }\end{array}$ & Durbin-Watson \\
\hline 1 &, $412^{\mathrm{a}}$ &, 170 &, 119 & 235,15961 & 1,273 \\
\hline
\end{tabular}

a. Predictors: (Constant), BOPO, ROA, CAR, DPK, PYD, ASET, NPF, FDR

b. Dependent Variable: PMS

Source: Secondary data, processed by SPSS 24, 2020

From the output, It can be concluded that the ASSET, PYD, TPF, NPF, CAR, FDR, ROA, BOPO Durbin-Watson scores are 1.273 or +1 , shows that the model does not show autocorrelation.

Table 5. Multiple Linear Regression Test Results

\begin{tabular}{|c|c|c|c|c|c|c|c|c|}
\hline \multicolumn{9}{|c|}{ Coefficients ${ }^{a}$} \\
\hline & & \multicolumn{2}{|c|}{ Unstandardized Coefficients } & \multirow{2}{*}{$\begin{array}{l}\text { Standardized } \\
\text { Coefficients } \\
\text { Beta }\end{array}$} & \multirow[b]{2}{*}{$t$} & \multirow[b]{2}{*}{ Sig. } & \multicolumn{2}{|c|}{ Collinearity Statistics } \\
\hline \multicolumn{2}{|c|}{ Model } & $\theta$ & Std. Error & & & & Tolerance & VIF \\
\hline \multirow[t]{9}{*}{1} & (Constant) & 158,466 & 35,083 & & 4,517 &, 000 & & \\
\hline & ASET & -232 & 227 &,- 083 & $-1,021$ & 309 & 960 & 1,041 \\
\hline & PYO &, 482 & 204 &, 189 & 2,359 &, 020 & 990 & 1,010 \\
\hline & DPK & 103 &, 032 & 256 & 3,195 &, 002 & 985 & 1,016 \\
\hline & NFF & 14,175 & 6,398 &, 180 & 2,215 &, 028 &, 962 & 1,040 \\
\hline & CAR &,- 340 & 349 &,- 078 &,- 975 & .331 & .986 & 1,014 \\
\hline & $\mathrm{FDR}$ &,- 896 & .473 & -154 & $-1,894$ & ,060 & .953 & 1,049 \\
\hline & ROA & .143 &, 205 &, 056 & 697 & .487 & 978 & 1,023 \\
\hline & BOPO & -015 &, 027 &,- 044 &,- 550 & 593 & 989 & 1,011 \\
\hline
\end{tabular}

Source: Secondary data, processed by SPSS 24, 2020 


\subsection{Secondary data, processed by SPSS 24, 2020}

The results of the t-test $\mathrm{H} 1$ obtained the number -1.021 with a significance value of 0.309 . Because the significance level is $>0.05$, then Assets (X1) have no effect on the Islamic Capital Market (Y) partially. The results of the t-test H2 obtained the number 2,359 with a significance value of 0.020 . Because the significance level is $<0.05$, PYD (X2) partially affects the Islamic Capital Market (Y). The results of the t-test H3 obtained the number 3.195 with a significance value of 0.002 . Because the significance level is $<0.05$, TPF (X3) has a partial effect on the Islamic Capital Market (Y). The results of the t-test H4 obtained the number 2.215 with a significance value of 0.028 . Because the level of significance $<0.05$, the NPF (X4) partially affects the Islamic Capital Market (Y).

The results of the t-test $\mathrm{H} 5$ obtained the number -0.975 with a significance value of 0.311 . Because the level of significance $>0.05$, then the CAR (X5) partially affects the Islamic Capital Market (Y). The results of the t-test H6 obtained the number -1.894 with a significance value of 0.060. Because the significance level is $>0.05$, then FDR (X6) has no effect on the Islamic Capital Market (Y) partially. The results of the t-test H7 obtained the number 0.697 with a significance value of 0.487 . Because the level of significance $>0.05$, then ROA (X7) does not affect the Stock Price (Y) partially. The results of the t-test H8 obtained the number 0.550 with a significance value of 0.583 . Because the significance level is $>0.05$, the BOPO (X8) has no effect on the Islamic Capital Market (Y) partially.

\begin{tabular}{llccccc}
\multicolumn{8}{c}{ Table 6. F-Test Results } \\
\hline \multicolumn{7}{c}{ ANOVA $^{\mathbf{a}}$} \\
\hline Model & Sum of Squares & df & Mean Square & F & Sig. \\
\hline 1 & Regression & 1483316,728 & 8 & 185414,591 & 3,353 &, $002^{\mathrm{b}}$ \\
& Residual & 7244305,781 & 131 & 55300,044 & & \\
& Total & 8727622,510 & 139 & & & \\
\hline \multicolumn{7}{c}{ Source: Secondary data, processed by SPSS 24, 2020 } \\
\end{tabular}

Criteria:

If $\mathrm{F}$ count $>\mathrm{F}$ table, then Ho is rejected and $\mathrm{Ha}$ is accepted.

If $\mathrm{F}$ count $<\mathrm{F}$ table, then $\mathrm{Ho}$ is accepted and $\mathrm{Ha}$ is rejected.

Or if $\mathrm{P}<0.05$, then Ho is rejected and Ha is accepted. If $\mathrm{P}>0.05$, then Ho is accepted and Ha is rejected.

With a significant level of $5 \%$ and degrees of freedom $\mathrm{dfl}=8$ and $\mathrm{df} 2=131$, the table obtained $F(8 ; 131)=2.01$. In the calculation, the calculated $F$ value is greater than $F$ table, which is $3.353>2.01$. so Ho is rejected. Meanwhile, if viewed from the calculated sig value is 0.002 , which is $<0.05$, the decision is also Ho accepted which means this shows that simultaneously there is an influence between ASSET, PYD, TPF, NPF, CAR, FDR, ROA, BOPO have an effect on the Islamic Capital Market, registered with OJK in 2011-2019.

Table 7. Coefficient of Determination Test Results (R2)

\begin{tabular}{cccccc}
\hline Model & R & R Square & $\begin{array}{c}\text { Mdjusted R } \\
\text { Square }\end{array}$ & $\begin{array}{c}\text { Std. Eor of } \\
\text { the Estimate }\end{array}$ & Durbin-Watson \\
\hline 1 &, $412^{\text {a }}$ &, 170 &, 119 & 235,15961 & 1,273 \\
\hline \multicolumn{5}{r}{ Source: Secondary data, processed by SPSS 24,2020} \\
\end{tabular}


The coefficient of determination adjusted R Square is 0.170 which indicates that $17 \%$ of the stock price is influenced by the variables ASSET, PYD, TPF, NPF, CAR, FDR, ROA, BOPO, the remaining 99.83\% of Islamic Capital Markets registered with OJK in 2011- 2019 is influenced by other variables outside the regression model.

\section{Conclusion}

Based on the partial hypothesis testing (t-test) that has been analyzed, it can be concluded as follows:

a. The Asset Variable (X1) has a significant effect on the Sharia Capital Market registered with the OJK in 2011-2019.

b. The PYD variable (X2) has a significant effect on the Sharia Capital Market registered with the OJK in 2011-2019.

c. The DPK variable (X3) has no significant effect on the Sharia Capital Market registered with the OJK in 2011-2019.

d. The NPF variable (X4) has no significant effect on the Sharia Capital Market registered with the OJK in 2011-2019.

e. The CAR variable (X2) has no significant effect on the Sharia Capital Market registered with the OJK in 2011-2019.

f. The FDR variable (X3) has a significant effect on the Islamic Capital Market registered with the OJK in 2011-2019.

g. The ROA variable (X3) has a significant effect on the Islamic Capital Market registered with the OJK in 2011-2019.

h. The BOPO variable (X1) has a significant effect on the Islamic Capital Market registered with the OJK in 2011-2019.

Variables ASSETS, PYD, TPF, NPF, CAR, FDR, ROA, BOPO, simultaneously affect the Sharia Capital Market registered with OJK in 2011-2019.

\section{References}

[1] Fatwa Dewan Syariah Nasional. Pasar Modal Dan Pedoman Umum Penerapan Prinsip Syariah Di Bidang Pasar Moda (2003)

[2] Wahyudiono. Mudah Membaca Laporan Keuangan. Jakarta: Raih Asa Sukses (Penebar Swadaya Grup). (2014)

[3] Otoritas Jasa keuangan. "Snapshoot Perbankan Syariah Indonesia." www.ojk.go.id. (2019)

[4] Otoritas jasa keuangan. "Perkembangan Aset, PYD Dan DPK." www.ojk.go.id. (2019)

[5] Sugiyono. Metode Penelitian Kuantitatif, Kualitatif Dan R\&D. Bandung: PT Alfabet. (2016)

[6] Sujarweni, V. Wiratna. Penelitian Akuntansi Dengan SPSS. Yogyakarta: Pustaka Baru Press. (2016)

[7] Ghozali, Imam. Aplikasi Analisis Multivariate Dengan Program IBM SPSS 19. Semarang: Universitas Diponegoro. (2011)

[8] Sugiyono. Metode Penelitian Pendidikan Pendekatan Kuantitatif, Kualitatif, Dan $R \& D$. Bandung: PT Alfabet. (2013) 
[9] Sugiyono. Metode Penelitian Pendidikan Pendekatan Kuantitatif, Kualitatif, Dan $R \& D$. Bandung: Alfabet. (2010)

[10] Muhammad. Manajemen Bank Syariah. Yogyakarta: UPP AMPYKPN (2005)

[11] Asri, Aida Sania, and Muhamad Syaichu. "Analisis Faktor - Faktor Yang Mempengaruhi Pembiayaan Berbasis Bagi Hasil Pada Perbankan Syariah Di Indonesia Periode 2010-2014.” Diponegoro Journal of Management 5 (3): 1-15 (2016)

[12] Al-Qur`an. n.d. Al-Nissa. Ayat 29.

[13] Destiana, Rina. "Analisis Dana Pihak Ketiga Dan Risiko Terhadap Pembiayaan Mudharabah Dan Musyarakah Pada Bank Syariah Di Indonesia” XVII (2): 42-54. (2016)

[14] Saputra. Saku Keperawatan Pasien Dengan Gangguan Fungsi Kardiovaskuler. Tangerang Selatan: Binarupa Aksara Publisher. (2014)

[15] Kuncoro. Manajemen Perbankan, Teori Dan Aplikasi. Jakarta: PT. Indeks Kelompok Gramedia.(2002)

[16] Tri Hendro \& Conny Chandra Rahardja. Bank \& Institusi Keuangan Non Bank Di Indonesia. Yogyakarta: UPP STIM YKPN. (2014)

[17] Sudarmawanti, Erna, and Joko Pramono. "Pengaruh CAR, NPL, BOPO, NIM Dan LDR Terhadap ROA (Studi Kasus Pada Bank Perkreditan Rakyat Di Salatiga Yang Terdaftar Di Otoritas Jasa Keuangan Tahun 2011 - 2015).” Among Makarti 10 (19): 118. (2017)

[18] Kasmir. Analisis Laporan Keuangan. Jakarta: PT. Raja Grafindo Persada (2012)

[19] Sofyan Harahap. Analisa Kritis Atas Laporan Keuangan. 11th ed. Jakarta: PT RajaGrafindo Persada. (2010)

[20] Subramanyam. Analisa Laporan Keuangan. Jakarta: Salemba Empat (2013).

[21] Kasmir. Analisis Laporan Keuangan. Jakarta: Raja Grafindo Persada. (2010)

[22] Dewi Irma Dwi Puspita. "Pengaruh Return on Asset, Return on Equity, Economic Value Added Dannet Profit Marginterhadap Harga Saham Di Bursa Efek Indonesia (Studi Pada Perusahaan Real Estate\& Property) Periode 2012-2016.” Ekonomi Bisnis 26, Nomor (2715-1662): 205-17 (2020).

[23] Hery. Analisis Laporan Keuangan. 1st ed. Yogyakarta: Center For Academic Publishing Services. (2015)

[24] Al-Qur'an. n.d. Ali Imran. Ayat 145.

[25] Otoritas Jasa Keuangan. "Sumber Hukum Pasar Modal Syariah." (2014) www.ojk.go.id. 